\title{
Lipoteichoic acid induces surfactant protein-A biosynthesis in human alveolar type II epithelial cells through activating the MEK1/2-ERK1/2-NF-KB pathway
}

\author{
Feng-Lin Liu', Chi-Yuan Chuang ${ }^{2}$, Yu-Ting Tai ${ }^{1}$, Hsiu-Lien Tang ${ }^{3}$, Tyng-Guey Chen ${ }^{1}$, Ta-Liang Chen ${ }^{4}$ \\ and Ruei-Ming Chen ${ }^{4,5,6^{*}}$
}

\begin{abstract}
Background: Lipoteichoic acid (LTA), a gram-positive bacterial outer membrane component, can cause septic shock. Our previous studies showed that the gram-negative endotoxin, lipopolysaccharide (LPS), could induce surfactant protein-A (SP-A) production in human alveolar epithelial (A549) cells.

Objectives: In this study, we further evaluated the effect of LTA on SP-A biosynthesis and its possible signal-transducing mechanisms.

Methods: A549 cells were exposed to LTA. Levels of SP-A, nuclear factor (NF)-kB, extracellular signal-regulated kinase 1/2 (ERK1/2), and mitogen-activated/extracellular signal-regulated kinase kinase (MEK)1 were determined.

Results: Exposure of A549 cells to 10, 30, and $50 \mu \mathrm{g} / \mathrm{ml}$ LTA for $24 \mathrm{~h}$ did not affect cell viability. Meanwhile, when exposed to $30 \mathrm{\mu g} / \mathrm{ml}$ LTA for 1, 6, and $24 \mathrm{~h}$, the biosynthesis of SP-A mRNA and protein in A549 cells significantly increased. As to the mechanism, LTA enhanced cytosolic and nuclear NF-KB levels in time-dependent manners. Pretreatment with BAY 11-7082, an inhibitor of NF-KB activation, significantly inhibited LTA-induced SP-A mRNA expression. Sequentially, LTA time-dependently augmented phosphorylation of ERK1/2. In addition, levels of phosphorylated MEK1 were augmented following treatment with LTA.
\end{abstract}

Conclusions: Therefore, this study showed that LTA can increase SP-A synthesis in human alveolar type II epithelial cells through sequentially activating the MEK1-ERK1/2-NF-KB-dependent pathway.

Keywords: Lipoteichoic acid, Alveolar epithelial cells, Surfactant protein-A, MEK/ERK/NF-kB

\section{Background}

Sepsis can lead to multiorgan failure and death and appears to be triggered by bacterial products, such as lipopolysaccharide (LPS) from gram-negative bacteria and lipoteichoic acid (LTA) from gram-positive ones [13]. Infection of the respiratory tract caused by grampositive bacteria and pneumonia combined with acute lung injury (ALI) are usually the leading causes of

\footnotetext{
* Correspondence: rmchen@tmu.edu.tw

${ }^{4}$ Anesthetics and Toxicology Research Center, Taipei Medical University Hospital, Taipei, Taiwan

${ }^{5}$ Graduate Institute of Medical Sciences; Center of Excellence for Cancer Research, Taipei Medical University, Taipei, Taiwan

Full list of author information is available at the end of the article
}

mortality by sepsis [4]. In the past few decades, the incidences of sepsis and septic shock have been increasing [5]. Although endotoxin-activated events are clearly important in gram-negative infection, gram-positive bacteria also have crucial roles, but less is known about host responses to them [6]. The increasing prevalence of sepsis from gram-positive bacterial pathogens necessitates a reevaluation of the basic assumptions about the molecular pathogenesis of ALI.

Alveolar epithelial type II cells contribute to the maintenance of mucosal integrity by modulating the production of surfactants [7]. Pulmonary surfactants play important roles in protecting the lung during endotoxininduced injury and infection $[8,9]$. Surfactant protein

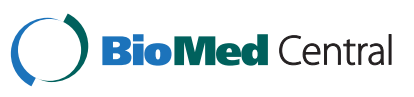


(SP)-A is the most abundant pulmonary surfactant protein. Levels of SP-A in bronchiolar lavage fluid are modulated in gram-negative or -positive bacteria-caused lung diseases, including severe pneumonia, acute respiratory distress syndrome, and cardiogenic lung edema [10]. Thus, altering lung SP-A levels can be an effective indicator for pulmonary infection and inflammation. Our previous study showed that LPS selectively induced $s p-a$ gene expression in human alveolar epithelial A549 cells [11].

LTA, an outer membrane component of gram-positive bacteria, was shown to be one of the critical factors participating in the pathogenesis of sepsis $[12,13]$. LTA can stimulate inflammatory responses in the lung $[14,15]$. Therefore, understanding the mechanisms that regulate LTA-mediated cell activation is crucial for diagnosis, treatment, or prognosis of lung inflammatory diseases. In response to stimuli, LTA can activate macrophages to produce massive amounts of inflammatory factors that exhibit systemic effects in the general circulation [16]. LTA can induce the secretion of various cytokines such as interleukin (IL)-1 $\beta$, IL-6, and tumor necrosis factor (TNF) $\alpha$ [17]. These data suggest that LTA can selectively modify gene transcription of various cell types and sequentially augment and possibly initiate tissue inflammation.

Mitogen-activated protein kinases (MAPKs) are serine/threonine kinases. The first MAPK isoforms to be cloned and characterized were the extracellular signalregulated kinase 1 and 2 (ERK 1/2) [18,19]. ERK $1 / 2$ are well documented to be activated by a family of dualspecificity kinases known as the mitogen-activated/ERK kinases (MEKs) [16,20]. A previous study demonstrated that LTA can selectively activate the ERK pathway in the cornea [21]. Our previous study showed that LTA induced TNF- $\alpha$ and IL- 6 expressions by means of stimulating phosphorylation of ERK1/2 in macrophages [16]. In addition, LTA also triggered translocation of nuclear factor (NF)- $\mathrm{kB}$ from the cytoplasm to nuclei and its transactivation activity. Meanwhile, the mechanisms responsible for LTA-induced $s p-a$ gene expression in alveolar epithelial cells are still unknown. In this study, we attempted to evaluate the effects of LTA on SP-1 synthesis in human alveolar type II epithelial cells and its possible mechanisms.

\section{Materials and methods}

\section{Cell culture and drug treatment}

A human lung carcinoma type II epithelial cell line (A549) was cultured following a previous method [3]. A549 cells were grown in Dulbecco's modified Eagle's medium (DMEM)/Ham's F12 culture medium (Sigma, St. Louis, MO, USA), supplemented with $10 \%(\mathrm{v} / \mathrm{v})$ heatinactivated fetal calf serum, $100 \mathrm{U} / \mathrm{ml}$ penicillin G, 100 $\mu \mathrm{g} / \mathrm{ml}$ streptomycin, and $2 \mathrm{mM}$ l-glutamine. A549 cells were seeded in $75-\mathrm{cm}^{2}$ culture flasks at $37{ }^{\circ} \mathrm{C}$ in a humidified atmosphere of $5 \% \mathrm{CO}_{2}$. Cells were grown to confluence before drug treatment. LTA purchased from Sigma was dissolved in phosphate-buffered saline (PBS) (0.14 M NaCl, $2.6 \mathrm{mM} \mathrm{KCl,} 8 \mathrm{mM} \mathrm{Na}_{2} \mathrm{HPO}_{4}$, and 1.5 $\mathrm{mM} \mathrm{KH_{2 }} \mathrm{PO}_{4}$ ). BAY 11-7082, an inhibitor of NF- $\mathrm{kB}$ activation, was also purchased from Sigma.

\section{Assay of cell viability}

Cell viability was determined using a colorimetric 3-(4,5dimethylthiazol-2-yl)-2,5-diphenyltetrazolium bromide assay as previously described [22]. Briefly, A549 cells $\left(10^{4}\right.$ cells/well) were seeded in 96-well tissue culture plates overnight. After drug treatment, macrophages were cultured in new medium containing $0.5 \mathrm{mg} / \mathrm{mL} 3-(4,5-$ dimethylthiazol-2-yl)-2,5-diphenyltetrazolium bromide for a further $3 \mathrm{~h}$. The blue formazan products in the macrophages were dissolved in dimethyl sulfoxide and spectrophotometrically measured at a wavelength of $550 \mathrm{~nm}$.

\section{Immunoblotting analyses of SP-A, NF-KB, and phosphorylated and non-phosphorylated ERK1/2 and MEK1}

Protein levels were immunodetected according to a previously described method [11]. After drug treatment, cell lysates were prepared in ice-cold radioimmunoprecipitation assay buffer (25 mM Tris- $\mathrm{HCl}(\mathrm{pH} 7.2), 0.1 \%$ sodium dodecylsulfate (SDS), 1\% Triton X-100, 1\% sodium deoxycholate, $0.15 \mathrm{M} \mathrm{NaCl}$, and $1 \mathrm{mM}$ EDTA). Protein concentrations were quantified using a bicinchonic acid protein assay kit (Pierce, Rockford, IL, USA). Proteins (50 $\mathrm{\mu g} /$ well) were subjected to sodium dodecylsulfate polyacrylamide gel electrophoresis (SDS-PAGE) and transferred to nitrocellulose membranes. Immunodetection of SP-A and NF- $\mathrm{KB}$ was carried out using rabbit polyclonal antibodies against human SP-A and NF- $\mathrm{KB}$ (Santa Cruz Biotechnology, Santa Cruz, CA, USA). Cellular $\beta$-actin protein was immunodetected using a mouse monoclonal antibody (mAb) against mouse $\beta$ actin (Sigma) as the internal standard. These protein bands were quantified using a digital imaging system (UVtec, Cambridge, UK). Phosphorylated ERK1/2 and MEK1 were immunodetected using a rabbit polyclonal antibody against phosphorylated residues of ERK1/2 and MEK1 (Cell Signaling, Danvers, MA, USA). Nonphosphorylated ERK2 and MEK1 were immunodetected as the internal controls (Cell Signaling). Intensities of the immunoreactive bands were determined using a digital imaging system (Wallac Victor 1420, PerkinElmer, Melbourne, Australia).

\section{Extraction of nuclear proteins and immunodetection}

Amounts of nuclear transcription factors were quantified following a previously described method [20]. After drug 
treatment, nuclear extracts of macrophages were prepared. Protein concentrations were quantified by a bicinchonic acid protein assay kit (Pierce, Rockford, IL, USA). Nuclear proteins $(50 \mu \mathrm{g} /$ well $)$ were subjected to SDS-PAGE and transferred to nitrocellulose membranes. After blocking, NF-kB was immunodetected using a rabbit polyclonal antibody against mouse NF-kB p65 (Santa Cruz Biotechnology). A proliferating cell nuclear antigen (PCNA) was detected using a mouse mAb against the rat PCNA protein (Santa Cruz Biotechnology) as the internal standard. Intensities of the immunoreactive bands were determined using a digital imaging system (Wallac Victor 1420, PerkinElmer).

\section{Real-time polymerase chain reaction (PCR) assays}

Messenger (m)RNA from A549 cells exposed to LTA were prepared for real-time PCR analyses of SP-A mRNA and $\beta$-actin mRNA. Oligonucleotides for the PCR analyses of SP-A mRNA and $\beta$-actin mRNA were designed and synthesized by Clontech Laboratories (Palo Alto, CA, USA). The oligonucleotide sequences of the upstream and downstream primers for these mRNA analyses were respectively 5'-TGA AAGGGAGTTCTAGCATCTCA CAGA-3' and 5'-ACATATGCCTATGTAGGCCTGACT GAG-3' for SP-A mRNA, and 5'- GTCTACATGTCTC GATCCCACTTA A -3' and 5'-GGTCTTTCTCTCTCAT CGCGCTC-5' for $\beta$-actin mRNA. A quantitative PCR analysis was carried out using iQSYBR Green Supermix (Bio-Rad, Hercules, CA, USA) and the MyiQ Single-Color Real-Time PCR Detection System (Bio-Rad) as described previously [11].

\section{Statistical analysis}

Statistical differences were considered significant when the $p$ value of Duncan's multiple-range test was $<0.05$. Statistical analysis between groups over time was carried out by a two-way analysis of variance (ANOVA).

\section{Results}

Toxicity of LTA to A549 cells

Cell morphology and viability were assayed to evaluate the toxicity of LTA to human alveolar epithelial A549 cells. Exposure of A549 cells to 10, 30, and $50 \mu \mathrm{g} / \mathrm{ml}$ LTA for $24 \mathrm{~h}$ did not affect cell viability (data not shown). When exposed to $30 \mu \mathrm{g} / \mathrm{ml}$ LTA for 1,6 , and 24 $\mathrm{h}$, the viability of A549 cells was not influenced. Exposure of A549 cells to $30 \mu \mathrm{g} / \mathrm{ml}$ LTA for 1,6 , and $24 \mathrm{~h}$ did not alter cell morphology (data not shown).

\section{LTA-induced enhancement of SP-A biosynthesis in A549 cells}

The effects of LTA on SP-A levels in A549 cells were evaluated by an immunoblotting analysis (Figure 1). In untreated A549 cells, low levels of SP-A were immunodetected
(Figure 1A, top panel, lane 1). After exposure to $30 \mu \mathrm{g} / \mathrm{ml}$ LTA for $1 \mathrm{~h}$, levels of SP-A were found to be augmented (lane 2). When treated for 6 and 24 h, LTA obviously increased amounts of SP-A in A549 cells. $\beta$-Actin was immunodetected (Figure 1A, bottom panel). These immunorelated protein bands were quantified and analyzed (Figure 1B). Exposure of A549 cells to $30 \mu \mathrm{g} / \mathrm{ml}$ LTA for 1 , 6 , and 24 h respectively caused significant $176 \%, 230 \%$, and $270 \%$ increases in SP-A levels.

\section{LTA-induced SP-A mRNA expression in A549 cells}

Induction of SP-A mRNA expression by LTA was quantified using a real-time PCR analysis (Figure 2). After exposure to LTA for $1 \mathrm{~h}$, the levels of SP-A mRNA in A549 cells were increased by 2.1-fold. Exposure of A549 cells to LTA for 6 and $24 \mathrm{~h}$ caused 2.8- and 3.7-fold increases in the levels of SP-A mRNA, respectively (Figure 2). Pretreatment of A549 cells with BAY 117082, an inhibitor of NF- $\mathrm{kB}$ activation, for $1 \mathrm{~h}$ did not change SP-A mRNA expression (data not shown). However, BAY 11-7082 significantly inhibited LTAinduced SP-A mRNA production by 70\% (Figure 2).

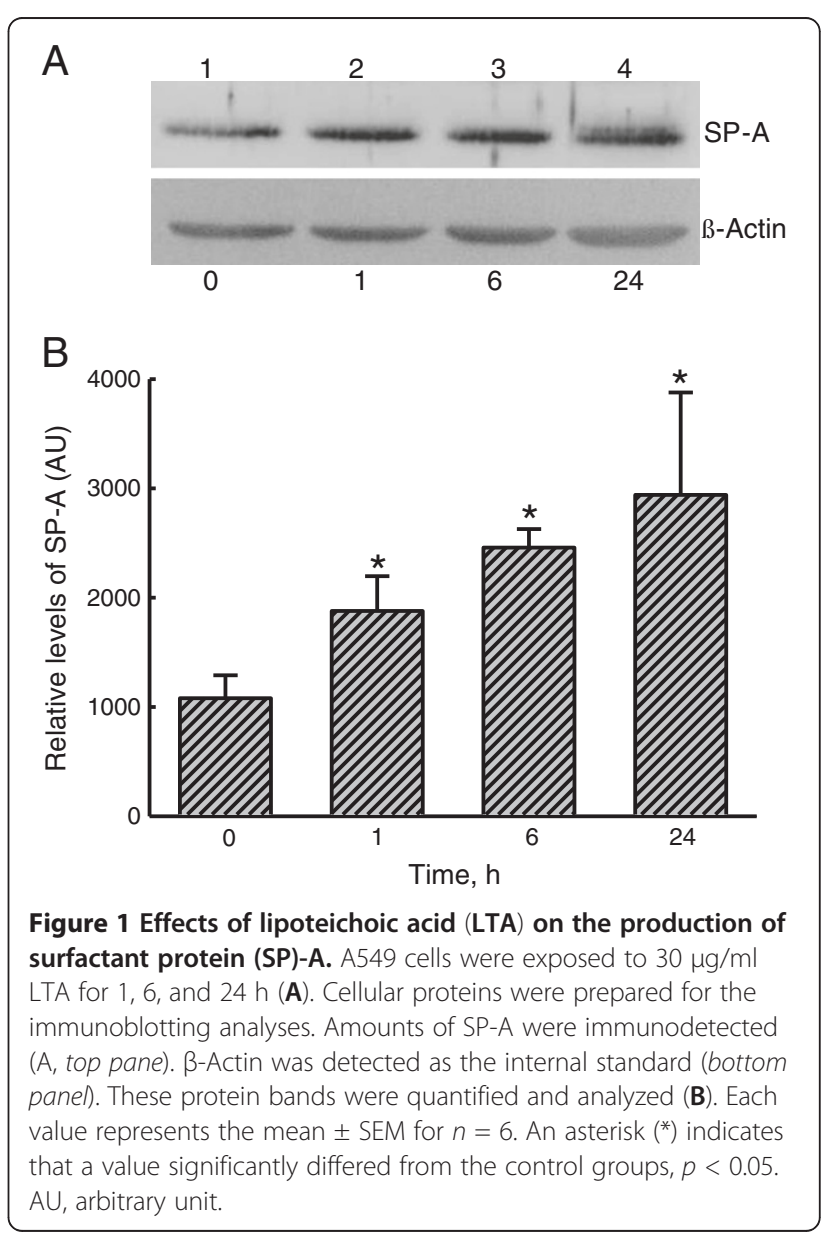




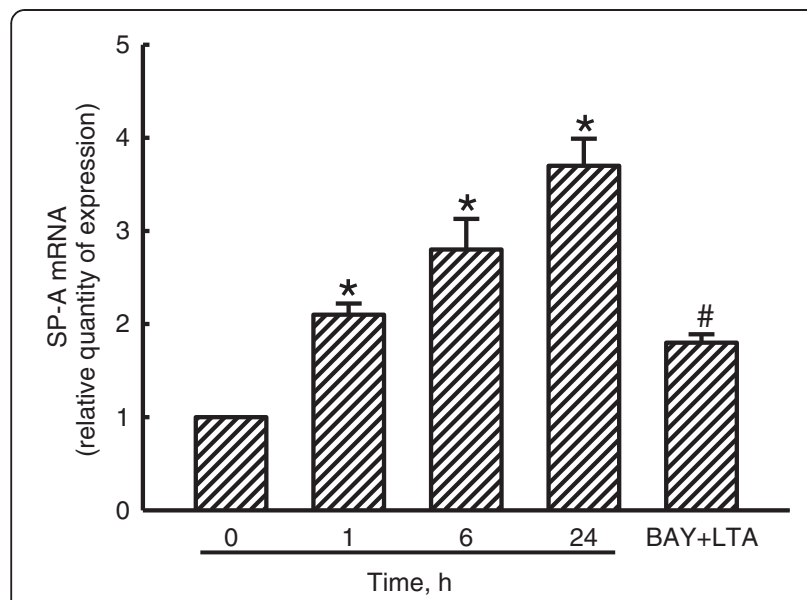

Figure 2 Effects of lipoteichoic acid (LTA) on induction of surfactant protein (SP)-A mRNA. A549 cells were exposed to 30 $\mathrm{\mu g} / \mathrm{ml} \mathrm{LTA}$ for 1,6 , and $24 \mathrm{~h}$. In addition, A549 cells were pretreated with BAY 11-7082 (BAY), an inhibitor of NF-KB activation, for $1 \mathrm{~h}$ and then exposed to LTA for another $24 \mathrm{~h}$. mRNA was prepared for real-time PCR analyses of SP-A mRNA and $\beta$-actin mRNA. Each value represents the mean \pm SEM for $n=3$. Symbols ${ }^{*}$ and \# indicate that the value significantly $(p<0.05)$ differed from the respective control and LTA-treated group, respectively.

\section{Augmentation of NF-KB expression and translocation by LTA}

Mechanisms of LTA-induced SP-A augmentation were evaluated by analyses of NF- $\mathrm{KB}$ expression and translocation (Figures 3 and 4). Exposure of A549 cells to LTA for $1 \mathrm{~h}$ enhanced levels of cytosolic NF-kB (Figure 3A, top panel, lane 1). After treatment for 6 and $24 \mathrm{~h}$, the expression of cytosolic NF- $\mathrm{B}$ was obviously augmented (lanes 3 and 4). $\beta$-Actin was immunodetected (Figure 3A, bottom panel). These immunorelated protein bands were quantified and analyzed (Figure 3B). Exposure of A549 cells to LTA for 1, 6, and 24 h significantly increased NF- $\mathrm{kB}$ production by $181 \%, 200 \%$, and $230 \%$, respectively.

Treatment of A549 cells with LTA for $1 \mathrm{~h}$ increased levels of nuclear NF-kB (Figure 4A, top panel, lane 2). When exposed for 6 and $24 \mathrm{~h}$, translocation of NF-kB from the cytoplasm to nuclei notably increased (lanes 3 and 4). Amounts of PCNA in A549 cells were immunodetected (Figure 4A, bottom panel). These immunorelated protein bands were quantified and analyzed (Figure 4B). Exposure of A549 cells to LTA for 1, 6, and $24 \mathrm{~h}$ respectively caused significant $176 \%, 340 \%, 530 \%$ enhancements in levels of nuclear NF-кB.

\section{LTA-enhanced phosphorylation of ERK1/2}

The reason why LTA improved NF- $\mathrm{kB}$ activation was further investigated by assaying ERK1/2 phosphorylation (Figure 5). Treatment of A549 cells with LTA for $1 \mathrm{~h}$ increased the amounts of phosphorylated ERK1/2

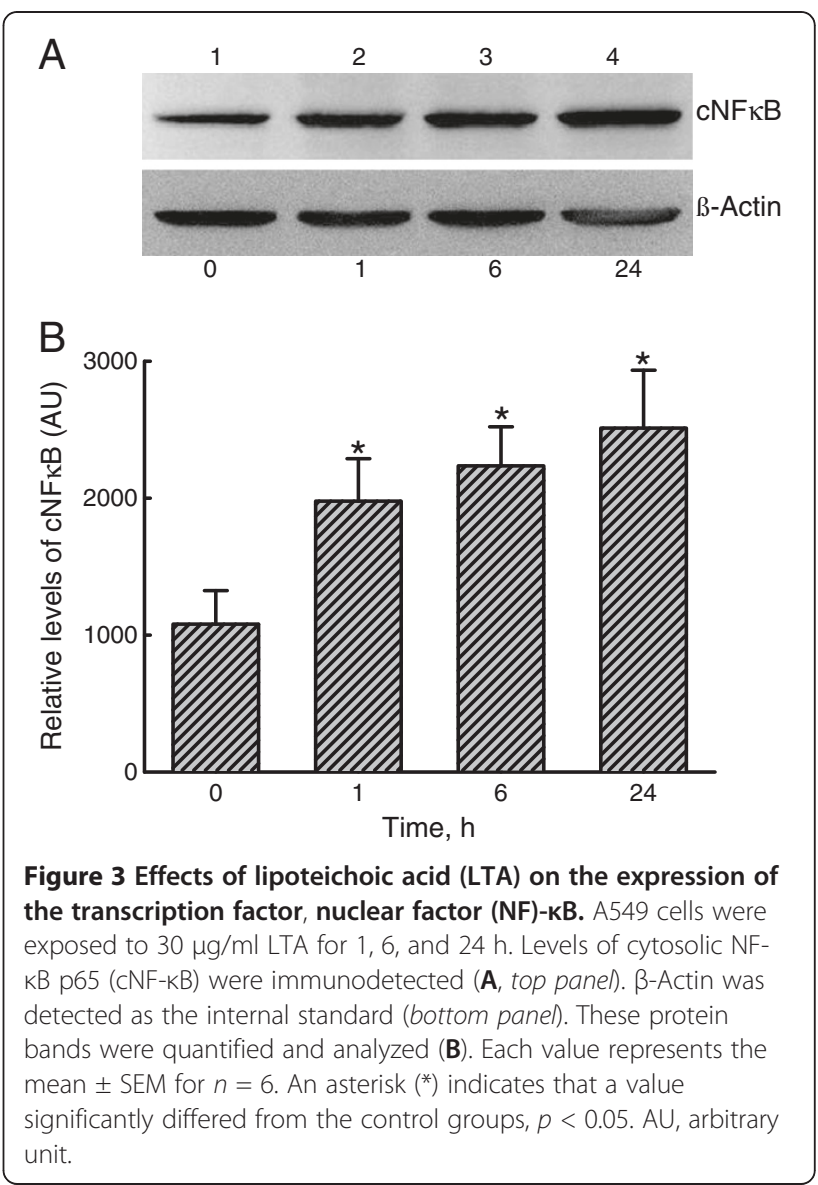

(Figure 5A, top panel, lane 2). Levels of phosphorylated ERK1/2 in A549 cells were obviously raised after exposure to LTA for 6 and $24 \mathrm{~h}$ (lanes 3 and 4). Amounts of $\beta$-actin in A549 cells were immunodetected (Figure 5A, bottom panel). These immunorelated protein bands were quantified and analyzed (Figure 5B). Exposure of A549 cells to LTA for 1,6 , and $24 \mathrm{~h}$ significantly increased ERK1 phosphorylation by $259 \%, 170 \%$, and $334 \%$, respectively. In comparison, levels of phosphorylated ERK2 were respectively augmented by 8.2-, 6.4-, and 7.8-fold following LTA administration for 1,6 , and $24 \mathrm{~h}$ (Figure 5B).

\section{LTA-induced activation of MEK1}

Phosphorylation of MEK1 was assayed to determine the mechanism of LTA-induced ERK1/2 activation (Figure 6). Low levels of phosphorylated MEK1 were detected in untreated A549 cells (Figure 6A, top panel, lane 1). However, exposure of A549 cells to LTA for $1 \mathrm{~h}$ stimulated MEK1 phosphorylation (lane 2). After exposure for 6 and $24 \mathrm{~h}$, the amounts of phosphorylated MEK1 had obviously increased (lanes 3 and 4). $\beta$-actin in A549 cells was immunodetected (Figure 6A, bottom panel). These immunorelated protein bands were quantified and analyzed 


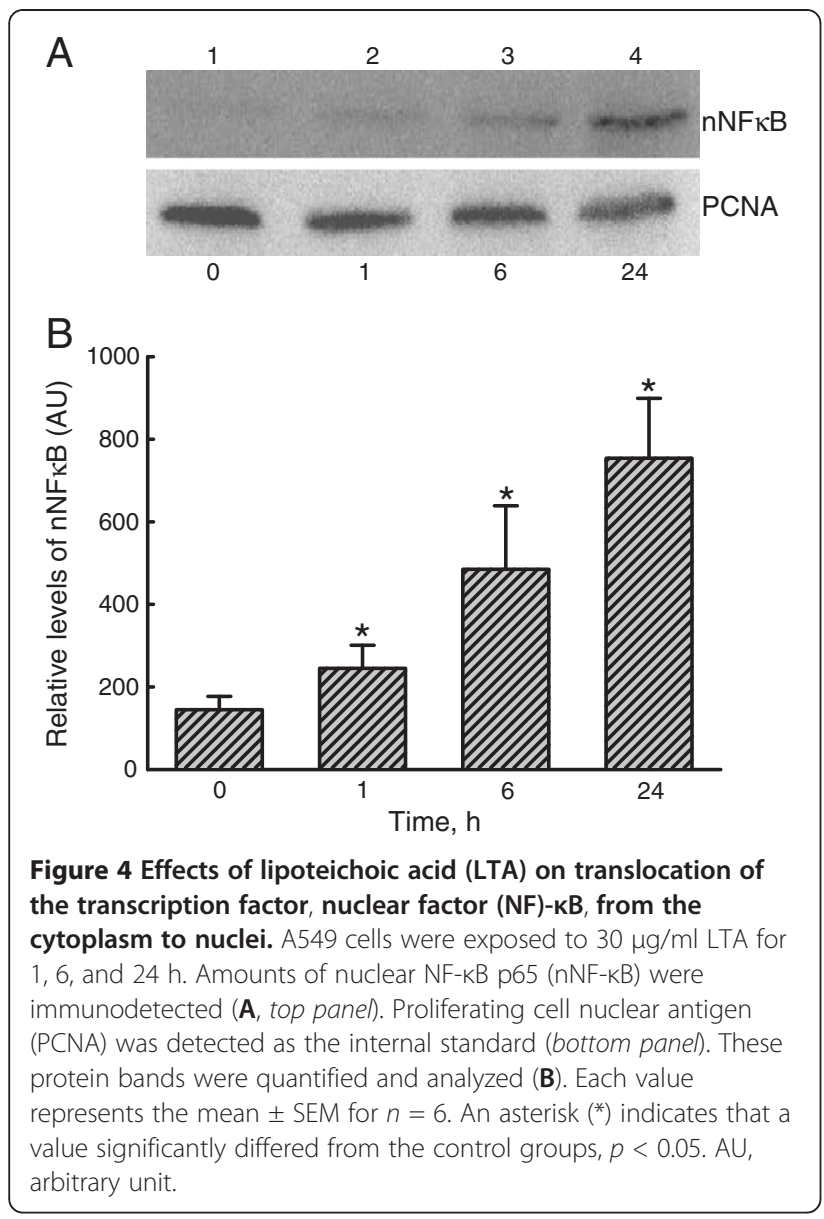

(Figure 6B). Treatment of A549 cells with LTA for 1, 6, and $24 \mathrm{~h}$ respectively caused significant $82 \%, 330 \%$, and $370 \%$ increases in levels of phosphorylated MEK1.

\section{Discussion}

LTA represents a class of amphiphilic molecules anchored to the outer face of the cytoplasmic membrane in gram-positive bacteria and is commonly released during cell growth, especially under antibiotic therapy $[1,2]$. It can cause cytokine induction in mononuclear phagocytes [17]. In previous studies, LTA concentrations of $0.2 \sim 50 \mu \mathrm{g} / \mathrm{ml}$ were detected and stimulated activity of polymononuclear leucocyte functions and release of TNF- $\alpha$ in peripheral blood mononuclear cells [23,24]. Meanwhile, LTA levels at the infectious site can reach a high level of 26,694 $\mathrm{ng} / \mathrm{mL}$ [25]. The concentration of LTA used in this study was $<50 \mu \mathrm{g} / \mathrm{ml}$. Therefore, our results show that LTA at clinically relevant concentrations can activate alveolar type II epithelial cells by stimulating production of surfactants.

During bacterial infection, endotoxins, including LTA and LPS, increase capillary permeability and enhance expressions of cellular adhesion molecules, proinflammatory cytokines, and chemokines [1,15]. These
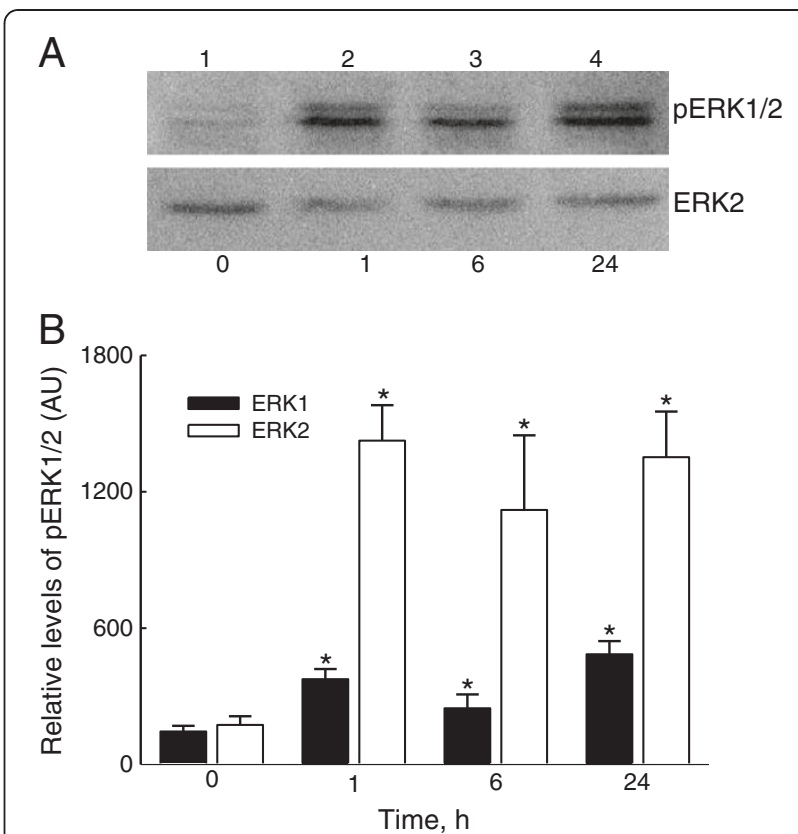

Figure 5 Effects of lipoteichoic acid (LTA) on the phosphorylation of extracellular signal-regulated kinase (ERK) 1/2. A549 cells were exposed to $30 \mu \mathrm{g} / \mathrm{ml}$ LTA for 1, 6, and 24 h. Phosphorylated ERK1/2 (p-ERK1/2) were immunodetected (A, top panel). ERK2 was detected as the internal standard (bottom panel). These immunorelated protein bands were quantified and analyzed (B). Each value represents the mean \pm SEM for $n=6$. An asterisk $\left(^{*}\right)$ indicates that a value significantly differed from the control group, $p<0.05$. AU, arbitrary unit.

endotoxins can lead to most of the clinical manifestations of bacterial infection and are associated with ALI $[4,5]$. In addition, LTA can trigger lung inflammation and causes neutrophil influx into the lungs $[15,26]$. This study showed that in response to LTA stimulation, levels of SP-A mRNA and protein in alveolar A549 cells were time-dependently augmented. SP-A contributes to the pulmonary host defense [10,16,27]. A previous study reported that when $s p$ - $a$ gene expression was knockedout, susceptibility of the lungs to pathogenic infection was simultaneously raised [28]. Our previous study also showed that LPS-mediated toll-like receptor (TLR) 2 signaling in human alveolar epithelial cells might increase SP-A biosynthesis and subsequently lead to an inflammatory response in the lungs [3]. As a result, SP-A could be an effective biomarker for detecting pulmonary infection by gram-negative or -positive bacteria.

This study showed that LTA increased the expression of NF- $\mathrm{BB}$ and its translocation from the cytoplasm to nuclei. NF- $\mathrm{kB}$ is a typical transcription factor in response to stimulation by LTA [16]. LTA can bind CD14 and then stimulates TLR activation [16,29]. After LTA associates with TLR2, NF-kB can be activated by protein kinases and is then translocated to nuclei from the cytoplasm [11]. NF- $\mathrm{kB}$ regulates certain gene expressions to 


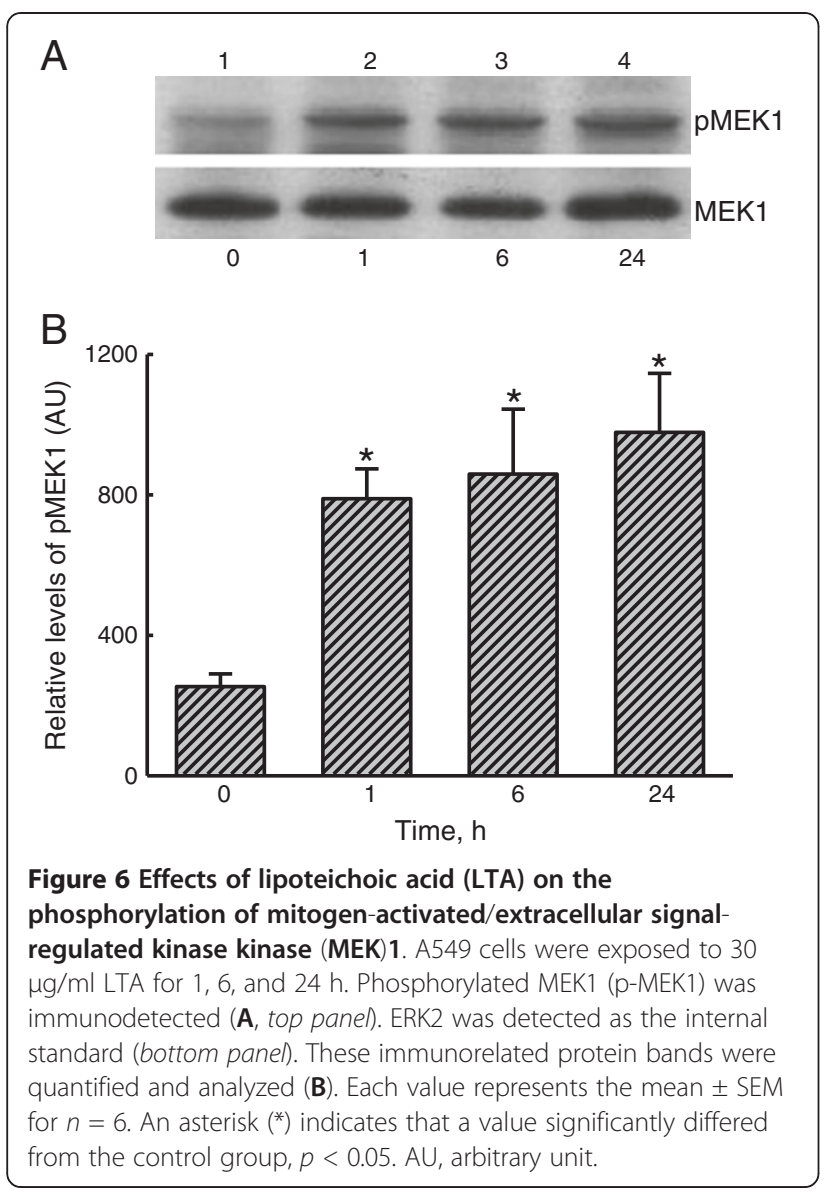

control cell proliferation, differentiation, and death $[30,31]$. A previous study showed that LTA induced cyclooxygenase-2 expression in epithelial cells via ІкB degradation and successive p65 NF- $\mathrm{kB}$ translocation [32]. LTA could induce SP-A mRNA expression in A549 cells. Our bioinformatic search revealed that NF-kBDNA-binding motifs were found in the promoter regions of the $s p-a$ gene. Suppressing NF- $\mathrm{KB}$ activation using BAY 11-7082 simultaneously inhibited LTAinduced SP-A mRNA expression. Thus, LTA transcriptionally induces SP-A expression through inducing NF- $\mathrm{kB}$ expression and translocation.

Our present results revealed that the phosphorylation of ERK1/2 was associated with NF- $\mathrm{kB}$ activation. Sequentially, ERK1/2-activated IкB $\alpha$ kinase can phosphorylate IKB at two conserved serine residues in the $\mathrm{N}$ terminus, triggering the degradation of this inhibitor and allowing for the rapid translocation of NF- $\mathrm{KB}$ into nuclei $[16,20]$. Accordingly, LTA-induced activation of A549 cells is mainly due to the improvement in ERK1/2 phosphorylation. Roles of ERK1 and ERK2 in LTA-induced SP-A expression were not determined in this study but will be validated using RNA interference in our next study. There is growing evidence that the ERK signaling pathway, which contributes to regulating inflammatory events [33]. Therefore, LTA regulates SP-A expression in alveolar type II epithelial cells in the course of eliciting ERK1/2 phosphorylation and subsequent activation of the transcription factor, NF- $\mathrm{KB}$.

ERK activation is mediated by at least three different pathways: a Raf/MEK-dependent pathway, a PI3K/Rafindependent pathway that strongly activates MEK, and a third undetermined pathway that directly activates ERK proteins [34]. This study showed that LTA timedependently increased levels of phosphorylated MEK1. Thus, one of the possible reasons explaining why LTA stimulates ERK1/2 activation is the increase in MEK1 phosphorylation. MAPK-regulating signals place this family of protein kinases in an apparently linear signaling cascade downstream of growth factor receptors, adaptor proteins, guanine-nucleotide exchange factors, Ras, Raf, and MEK [19]. The present study demonstrates that LTA can induce SP-A expression via MEKdependent activation of the protein kinase ERK1/2-signaling pathway.

\section{Conclusions}

In summary, we used an alveolar epithelial cell model to study the immunomodulatory responses of LTA. Our results revealed that LTA can induce inflammatory responses in alveolar epithelial A549 cells by means of enhancing SP-A mRNA and protein syntheses. Moreover, the signal-transducing mechanisms of LTA-caused regulation of SP-A expression arise through the cascade phosphorylations of MEK1 and ERK1/2. In succession, LTA increased NF- $\mathrm{kB}$ expression and translocation. LTA-induced SP-A production in alveolar type II epithelial cells may indicate the status of gram-positive bacteria-caused septic shock and acute lung injury. More molecular pathways should be investigated and proven in the future. However, there are certain limitations of this study, including the use of A549 cells, which are derived from human lung carcinoma. The effects of LTA on A549 cells may differ from those on normal alveolar epithelial cells. Thus, we will perform a translational study to evaluate the effects of LTA on alveolar epithelial cells of animals with acute lung injury.

\section{Abbreviations \\ ALI: Acute lung injury; ERK1/2: Extracellular signal-regulated kinase 1/2; IL: Interleukin; LPS: Lipopolysaccharide; LTA: Lipoteichoic acid; NF-kB: Nuclear factor-kB; MAPKs: Mitogen-activated protein kinases; MEK1: Mitogen- activated/extracellular signal-regulated kinase kinase 1; PCNA: Proliferating cell nuclear antigen; SDS-PAGE: Sodium dodecylsulfate polyacrylamide gel electrophoresis; SP-A: Surfactant protein-A; TLR2: Toll-like receptor 2; TNF-a: Tumor necrosis factor-a.}

\section{Competing interests}

The authors declare that they have no competing interests. 


\section{Authors' contributions}

FLL, CYC, and RMC visualized experimental design. YTT and HLT refined the experimental approach. TGC did the statistical analysis. TLC had significant intellectual input into the development of this work, and added to the Discussion. All authors reviewed data and results, and had significant input into the writing of the final manuscript. All authors read and approved the final manuscript.

\section{Acknowledgments}

This study was supported by the Department of Health, Taipei City Government (10101-10-007), the Department of Health (DOH101-TD-C-111008), and the National Science Council (NSC 100-2314-B-038-010-MY3 (2/3) Taipei, Taiwan.

\section{Author details}

'Department of Anesthesiology, Taipei Medical University-Wan Fang Hospital, Taipei, Taiwan. ${ }^{2}$ Division of Pulmonology, Department of Internal Medicine, Ren-Ai Branch, Taipei City Hospital, Taipei, Taiwan. ${ }^{3}$ Department of Rehabilitation, Po-Jen General Hospital, Taipei, Taiwan. ${ }^{4}$ Anesthetics and Toxicology Research Center, Taipei Medical University Hospital, Taipei, Taiwan. ${ }^{5}$ Graduate Institute of Medical Sciences; Center of Excellence for Cancer Research, Taipei Medical University, Taipei, Taiwan. ${ }^{6}$ Cell Physiology and Molecular Image Research Center, Taipei Medical University-Wan Fang Hospital, Taipei, Taiwan.

Received: 7 June 2012 Accepted: 1 October 2012

Published: 3 October 2012

\section{References}

1. von Aulock S, Morath S, Hareng L, Knapp S, van Kessel KP, van Strijp JA, Hartung T: Lipoteichoic acid from Staphylococcus aureus is a potent stimulus for neutrophil recruitment. Immunobiology 2003, 208:413-422.

2. Cohen J: The immunopathogenesis of sepsis. Nature 2002, 420:885-891.

3. Chuang CY, Chen TG, Tai YT, Chen TL, Lin YH, Tsai CH, Chen RM: Toll-like receptor 2-mediated sequential activation of MyD88 and MAPKs contributes to lipopolysaccharide-induced $s p-a$ gene expression in human alveolar epithelial cells. Immunobiology 2011, 216:707-714.

4. Linder A, Soehnlein $\mathrm{O}$, Akesson P: Roles of heparin-binding protein in bacterial infections. J Innate Immun 2010, 2:431-438.

5. Laupland KB, Kirkpatrick AW, Delaney A: Polyclonal intravenous immunoglobulin for the treatment of severe sepsis and septic shock in critically ill adults: a systematic review and meta-analysis. Crit Care Med 2007, 35:2686-2692.

6. Legrand $M$, Klijn E, Payen D, Ince C: The response of the host microcirculation to bacterial sepsis: does the pathogen matter? J Mol Med 2010, 88:127-133.

7. Rooney SA: Regulation of surfactant secretion. Comp Biochem Physiol A: Mol Integr Physiol 2001, 129:233-243.

8. Epaud R, Ikegami M, Whitsett JA, Jobe AH, Weaver TE, Akinbi HT: Surfactant protein B inhibits endotoxin-induced lung inflammation. Am J Respir Cell Mol Biol 2003, 28:373-378.

9. Raychaudhuri B, Abraham S, Bonfield TL, Malur A, Deb A, DiDonato JA, Kavuru MS, Thomassen MJ: Surfactant blocks lipopolysaccharide signaling by inhibiting both mitogen-activated protein and lkappaB kinases in human alveolar macrophages. Am J Respir Cell Mol Biol 2004, 30:228-232.

10. Gunther A, Ruppert C, Schmidt R, Markart P, Grimminger F, Walmrath D, Seeger W: Surfactant alteration and replacement in acute respiratory distress syndrome. Respir Res 2001, 2:353-364.

11. Chuang CY, Chen TL, Chen RM: Molecular mechanisms of lipopolysaccharide caused induction of surfactant protein-A gene expression in human alveolar epithelial A549 cells. Toxicol Lett 2009 191:132-139.

12. Wang JE, Dahle MK, McDonald M, Foster SJ, Aasen AO, Thiemermann C: Peptidoglycan and lipoteichoic acid in gram-positive bacterial sepsis: receptors, signal transduction, biological effects, and synergism. Shock 2003, 20:402-414.

13. Chuang CY, Chen TL, Cherng YG, Tai YT, Chen TG, Chen RM: Lipopolysaccharide induces apoptotic insults to human alveolar epithelial A549 cells through reactive oxygen species-mediated activation of an intrinsic mitochondrion-dependent pathway. Arch Toxicol 2011, 85:209-218.
14. Lemjabbar $\mathrm{H}$, Basbaum C: Platelet-activating factor receptor and ADAM10 mediate responses to Staphylococcus aureus in epithelial cells. Nat Med 2002, 8:41-46

15. Leemans JC, Heikens M, van Kessel KP, Florquin S, van der Poll T: Lipoteichoic acid and peptidoglycan from Staphylococcus aureus synergistically induce neutrophil influx into the lungs of mice. Clin Diagn Lab Immunol 2003, 10:950-953.

16. Chang HC, Lin KH, Tai YT, Chen JT, Chen RM: Lipoteichoic acid-induced TNF- $a$ and IL- 6 gene expressions and oxidative stress production in macrophages are suppressed by ketamine through downregulating tolllike receptor 2-mediated activation of ERK1/2 and NF-KB. Shock 2010, 33:485-492.

17. Greenfield EM, Beidelschies MA, Tatro JM, Goldberg VM, Hise AG: Bacterial pathogen-associated molecular patterns stimulate biological activity of orthopaedic wear particles by activating cognate Toll-like receptors. J Biol Chem 2010, 285:32378-32384.

18. Chiu WT, Lin YL, Chou CW, Chen RM: Propofol inhibits lipoteichoic acidinduced iNOS gene expression in macrophages possibly through downregulation of toll-like receptor 2-mediated activation of Raf-MEK1/ 2-ERK1/2-IKK-NFKB. Chem-Biol Interact 2009, 181:430-439.

19. Gild ML, Bullock M, Robinson BG, Clifton-Bligh R: Multikinase inhibitors: a new option for the treatment of thyroid cancer. Nat Rev Endocrinol 2011, 7:617-624.

20. Wu TT, Chen TL, Loon WS, Tai YT, Cherng YG, Chen RM: Lipopolysaccharide stimulates syntheses of toll-like receptor 2 and surfactant protein-A in human alveolar epithelial A549 cells through upregulating phosphorylation of MEK1 and ERK1/2 and sequential activation of NF-KB. Cytokine 2011, 55:40-47.

21. You L, Kruse FE, Bacher S, Schmitz ML: Lipoteichoic acid selectively induces the ERK signaling pathway in the cornea. Invest Ophth Vis Sci 2002, 43:2272-2277.

22. Chang HC, Chen TL, Chen RM: Interruption of hepatocyte cytoskeletons by ketamine occurs through suppression of calcium mobilization and mitochondrial function. Drug Metab Dipos 2009, 37:24-31.

23. Lotz S, Aga E, Wilde I, van Zandbergen G, Hartung T, Solbach W, Laskay T: Highly purified lipoteichoic acid activates neutrophil granulocytes and delays their spontaneous apoptosis via CD14 and TLR2. J Leukoc Biol 2004, 75:467-477.

24. Morath S, Geyer A, Hartung T: Structure-function relationship of cytokine induction by lipoteichoic acid from Staphylococcus aureus. J Exp Med 2001, 193:393-397.

25. Schneider O, Michel U, Zysk G, Dubuis O, Nau R: Clinical outcome in pneumococcal meningitis correlates with CSF lipoteichoic acid concentrations. Neurology 1999, 53:1584-1587.

26. Palaniyar N, Nadesalingam J, Reid KB: Pulmonary innate immune proteins and receptors that interact with gram-positive bacterial ligands. Immunobiology 2002, 205:575-594.

27. Khubchandani KR, Snyder JM: Surfactant protein A (SP-A): the alveolus and beyond. FASEB J 2001, 15:59-69.

28. LeVine AM, Whitsett JA, Gwozdz JA, Richardson TR, Fisher JH, Burhans MS, Korfhagen TR: Distinct effects of surfactant protein A or D deficiency during bacterial infection on the lung. I Immunol 2000, 165:3934-3940.

29. Schroder NW, Morath S, Alexander C, Hamann L, Hartung T, Zahringer U, Gobel UB, Weber JR, Schumann RR: Lipoteichoic acid of Streptococcus pneumoniae and Staphylococcus aureus activates immune cells via Toll-like receptor-2, lipopolysaccharide-binding protein, and CD14, whereas TLR-4 and MD-2 are not involved. J Biol Chem 2003, 278:15587-15594.

30. Dichtl W, Nilsson L, Goncalves I, Ares MP, Banfi C, Calara F, Hamsten A, Eriksson $P$, Nilsson J: Very low density lipoprotein activates nuclear factor-kappa B in endothelial cells. Circ Res 1999, 84:1085-1094.

31. Lacasa D, Taleb S, Keophiphath M, Miranville A, Clement K: Macrophage secreted factors impair human adipogenesis: involvement of proinflammatory state in preadipocytes. Endocrinology 2007, 148:868-877.

32. Lin CH, Kuan IH, Lee HM, Lee WS, Sheu JR, Ho YS, Wang CH, Kuo HP: Induction of cyclooxygenase-2 protein by lipoteichoic acid from Staphylococcus aureus in human pulmonary epithelial cells: involvement of a nuclear factor-kB-dependent pathway. Brit J Pharmacol 2001, 134:543-552. 
33. Bates ME, Green VL, Bertics PJ: ERK1 and ERK2 activation by chemotactic factors in human eosinophils is interleukin 5-dependent and contributes to leukotriene C(4) biosynthesis. J Biol Chem 2000, 275:10968-10975.

34. Pizon V, Baldacci G: Rap1A protein interferes with various MAP kinase activating pathways in skeletal myogenic cells. Oncogene 2000, 19:6074-6081.

doi:10.1186/1465-9921-13-88

Cite this article as: Liu et al:: Lipoteichoic acid induces surfactant protein-A biosynthesis in human alveolar type II epithelial cells through activating the MEK1/2-ERK1/2-NF-KB pathway. Respiratory Research 2012 13:88.

\section{Submit your next manuscript to BioMed Central and take full advantage of:}

- Convenient online submission

- Thorough peer review

- No space constraints or color figure charges

- Immediate publication on acceptance

- Inclusion in PubMed, CAS, Scopus and Google Scholar

- Research which is freely available for redistribution 